\title{
Combined toxicity of mercury and cadmium to the tropical green mussel Perna viridis
}

\author{
C. V. Mohan ${ }^{1}$, T. R. C. Gupta ${ }^{1}$, H. P. C. Shetty ${ }^{1} \&$ N. R. Menon ${ }^{2, *}$ \\ ${ }^{1}$ College of Fisheries, University of Agricultural Sciences, Mangalore -575002 , India \\ ${ }^{2}$ Marine Biology, Microbiology \& Biochemistry Division, School of Marine Sciences, Cochin University of Science and \\ Technology, Cochin-682 016, India
}

\begin{abstract}
Effects were studied of mercury and cadmium individually and in combination on survival, byssus thread production, oxygen consumption and filtration rate of the intertidal bivalve Perna viridis (L.). Mercury and cadmium in mixtures interacted more-than-additively (synergism) in producing mortality in $96 \mathrm{~h}$. Reduction in byssus-thread production, oxygen consumption and filtration rate recorded at sublethal levels of mercury-cadmium mixtures, however, was either less than or more than additive. Less than additive responses probably indicate ion antagonism.
\end{abstract}

\section{INTRODUCTION}

Pollution of the aquatic environment by heavy metals has received considerable attention in recent years (for reviews see Davies 1978, Eisler 1979, Bryan 1984) owing to their toxicity at very low levels, persistence in the environment, and their ability to accumulate in animal tissues. It is well known that metal toxicants seldom occur individually in the aquatic environment. Industrial effluents and agricultural run-offs into aquatic systems almost certainly burden the ecosystem with mixtures of toxic, or potentially toxic, metals. Despite the considerable amount of information available on the effects of individual heavy metals on aquatic organisms, reports on adverse effects of heavy-metal mixtures to aquatic organisms and their interactions at lethal and sublethal levels are quite limited. The importance of complex mixtures of toxicants in determining water-quality criteria and setting guidelines in effluent discharge has been emphasized by Sprague (1970), Marking \& Dawson (1975), Spehar et al. (1978), Weis (1978), Weis \& Weis (1978), and Wong et al. (1978).

Several studies have stressed possible deleterious effects of mercury or cadmium on aquatic organisms at lethal and sublethal levels (Eisler 1971, Calabrese \& Nelson 1974, Waldichuk 1974, Johnston 1976, Nelson et al. 1976, 1977, Reish \& Carr 1978, Briggs 1979,

\footnotetext{
- Addressee for correspondence
}

Eknath \& Menon 1979, George \& Frazier 1982, George 1983, Mohan et al. 1984).

The results presented in this paper report effects of mercury and cadmium individually and in combination on survival and metabolism of the tropical intertidal bivalve Perna viridis, which could be an important candidate in the 'Mussel Watch' programme (Goldberg et al. 1978).

\section{MATERLALS AND METHODS}

Perna viridis (L.) of 20 to $25 \mathrm{~mm}$ shell length were collected from the Someshwar rocky shore $\left(12^{\circ} 47^{\prime} \mathrm{N}\right.$, $74^{\circ} 51^{\prime} \mathrm{E}$ ), along the coast of Mangalore (India) from low tide level and kept in raw seawater $(35 \%)$ at room temperature $\left(28^{\circ} \mathrm{C} \pm 1 \mathrm{C}^{\circ}\right)$ for $72 \mathrm{~h}$ prior to the experiments. Raw seawater was collected from the unpolluted area off Someshwar beach, the habitat of the test animal. The seawater was stablised, sanitised and filtered by passing through a biofilter prior to use. Salinity ranged between 34.0 and $35.5 \%$, pH between 8.15 and 8.30 .

Ten mussels of 20 to $25 \mathrm{~mm}$ shell length were used for each test concentration. They were exposed to either mercury, cadmium or a combination of $\mathrm{Hg}$ and $\mathrm{Cd}$ for toxicity evaluation. Analar grade mercuric chloride and cadmium chloride formed the source of the metals. Mussels were inspected every $12 \mathrm{~h}$, and were considered dead if they gaped beyond $5 \mathrm{~mm}$ and 
showed no mantle retraction or foot movements on mechanical stimulation. Sublethal effects were followed by assessing the performance of the mussel in byssogenesis, oxygen uptake and filtration rate.

Byssus threads, secreted by the pedal gland, help in mooring the mussel to a hard substratum. The rate of thread formation gives an idea of the scope for activity. Estimates of the energy budget of Mytilus edulis have shown that $44 \%$ of carbon and $21 \%$ of nitrogen of the total energy intake are utilised by a healthy specimen towards byssus production (Hawkins 1985, Hawkins \& Bayne 1985).

The total number of byssus threads produced by 10 mussels during $96 \mathrm{~h}$ (12 h light and $12 \mathrm{~h}$ dark alternatively for 4 d), under different metal concentrations, were counted and averaged to obtain the rate of byssogenesis.

To study oxygen uptake, mussels were pre-exposed to selected toxicant concentrations for $24 \mathrm{~h}$. Ten individuals were kept in glass containers with $2 \mathrm{l}$ of test solution and the containers were sealed with inert liquid paraffin in order to avoid exchange of gases with the atmosphere. The experiment was run for 10 to $12 \mathrm{~h}$; water samples were drawn every $2 \mathrm{~h}$ and analysed for oxygen. The values represented are therefore averages of 5 or 6 readings, recorded from each test concentration. Results were expressed as $\mu \mathrm{g}$ oxygen consumed $\mathrm{mg}^{-1}$ dry weight $\mathrm{h}^{-1}$.

To assess the rate of filtration, a dye clearance technique was employed involving addition of a known concentration of Neutral red to the test solution so as to achieve $2.0 \mathrm{ppm}$ and allowing the mussels to clear the dye. The reduction in dye concentration at fixed intervals was estimated colorimetrically (420 to $480 \mathrm{~nm})$. Filtration rate was estimated using Quayle's (1948) equation.

To determine the toxicity of metal mixtures, the additive toxicity index developed by Marking \& Dawson (1975) was used. The toxicity unit, or sum of the biological effects of metal mixtures, is calculated based on the formula

$$
\frac{\mathrm{Am}}{\mathrm{Ai}}+\frac{\mathrm{Bm}}{\mathrm{Bi}}=\mathrm{S}
$$

where $\mathrm{A}$ and $\mathrm{B}=$ metals; subscripts $\mathrm{i}$ and $\mathrm{m}=$ toxicities (the $96 \mathrm{~h} \mathrm{LC}_{50}$ values) of the individual metal and metal mixtures respectively; $\mathrm{S}=$ sum of biological effects. The following relation is used to arrive at an appropriate index:

$\frac{1}{S}-1$ for $S \leq 1$ (greater-than-additive toxicity)

$$
S(-1)+1 \text { for } S \geq 1 \text { (less-than-additive toxicity) }
$$

When an index is negative, it indicates less-thanadditive toxicity, zero indicates additive toxicity and a positive value, more-than-additive. If the $95 \%$ confidence limits overlap zero, it is considered as simple additivity.

Lethal and sublethal toxicites of $\mathrm{Hg}$ and $\mathrm{Cd}$ were assessed first, and then their combined toxicity. Metalmetal combinations are shown as effects of different $\mathrm{Hg}$ concentrations in combination with a constant $\mathrm{Cd}$ concentration, and vice versa. Combinations are represented as $(\mathrm{Hg}+\mathrm{Cd})$ for $\mathrm{Hg}$ varying and $\mathrm{Cd}$ constant, and $(\mathrm{Cd}+\mathrm{Hg})$ for $\mathrm{Cd}$ varying and $\mathrm{Hg}$ constant.

\section{RESULTS}

Table 1 gives $\mathrm{LC}_{50}$ values, and Table $2 \mathrm{ET}_{50}$ values, for $\mathrm{Hg}$ and $\mathrm{Cd}$ individually and in combination. The $96 \mathrm{~h} \mathrm{LC}_{50}$ values for $\mathrm{Hg}$ and $\mathrm{Cd}$ were 0.23 and $2.5 \mathrm{ppm}$ respectively (Table 1). The $\mathrm{Hg}+\mathrm{Cd}$ mixture, in which concentrations ranged from 0.02 to $0.18 \mathrm{ppm} \mathrm{Hg}$ with a constant $0.8 \mathrm{ppm}$ of $\mathrm{Cd}_{1}$ produced $\mathrm{LC}_{50}$ values (as toxic

Table 1. Perna viridis. $\mathrm{LC}_{50}(\mathrm{ppm})$ upon exposure to $\mathrm{Hg}, \mathrm{Cd},(\mathrm{Hg}+\mathrm{Cd})$ and $(\mathrm{Cd}+\mathrm{Hg})$ salts over periods up to $96 \mathrm{~h}$ with respective

\begin{tabular}{|c|c|c|c|c|}
\hline Time $(\mathrm{h})$ & $\mathrm{Hg}$ & $\mathrm{Cd}$ & $\mathrm{Hg}+\mathrm{Cd}(0.8 \mathrm{ppm})$ & $\mathrm{Cd}+\mathrm{Hg}(0.12 \mathrm{ppm})$ \\
\hline 48 & 1.00 & - & 0.13 & 0.12 \\
\hline 60 & 0.52 & 7.0 & 0.085 & 0.72 \\
\hline 72 & 0.25 & 5.0 & 0.07 & 0.60 \\
\hline 84 & 0.23 & 3.1 & 0.05 & 0.42 \\
\hline \multirow[t]{3}{*}{96} & 0.23 & 2.5 & 0.045 & 0.35 \\
\hline & $(0.21-0.25)^{\circ}$ & $(2.4-2.55)^{\circ}$ & $(0.042-0.046)^{\circ}$ & $(0.33-0.36)^{\circ}$ \\
\hline & Additive $\mathbf{i}$ & & & \\
\hline $\mathrm{Hg}+\mathrm{Cd}$ & $+0.92 \cdots$ & $(0.89-0.95)^{\circ}$ & & \\
\hline $\mathrm{Cd}+\mathrm{Hg}$ & $+0.52 \cdots$ & $(0.49-0.54)^{\circ}$ & & \\
\hline $\begin{array}{l}\text { - } 95 \% \text { confiden } \\
\text { - More than add }\end{array}$ & & & & \\
\hline
\end{tabular}
additive indices 
Table 2. Perna viridis. $\mathrm{ET}_{50}(\mathrm{~h})$ (effective time to kill $50 \%$ of test population) when exposed to $\mathrm{Hg}, \mathrm{Cd},(\mathrm{Hg}+\mathrm{Cd})$ and $(\mathrm{Cd}+\mathrm{Hg})$ as a function of concentration

\begin{tabular}{|ccccc|}
\hline $\begin{array}{c}\text { Metal } \\
\text { concentration } \\
\text { (ppm) }\end{array}$ & $\mathrm{Hg}$ & $\mathrm{Cd}$ & $\begin{array}{c}\mathrm{Hg}+\mathrm{Cd} \\
(0.8 \mathrm{ppm})\end{array}$ & $\begin{array}{c}\mathrm{Cd}+\mathrm{Hg} \\
(0.12 \mathrm{ppm})\end{array}$ \\
\hline 0.04 & & & 110.0 & \\
0.06 & & & 73.3 & \\
0.08 & & & 65.0 & \\
0.12 & & & 48.3 & \\
0.15 & & & 45.0 & \\
0.30 & 68.33 & & & 83.3 \\
0.40 & & & & 73.3 \\
0.50 & 63.33 & & & 60.0 \\
0.60 & & & & \\
0.75 & 55.00 & & & \\
0.80 & & & & \\
1.00 & 51.66 & & & \\
1.20 & & & & \\
4.0 & & 76.66 & & \\
5.0 & & 65.0 & & \\
10.0 & & 48.33 & & \\
\hline
\end{tabular}

units) as follows: $48 \mathrm{~h}, 0.89 ; 60 \mathrm{~h}, 0.69 ; 84 \mathrm{~h}, 0.54 ; 96 \mathrm{~h}$, 0.52 . The additive index calculated for the $96 \mathrm{~h} \mathrm{LC}_{50}$ $(\mathrm{Hg}+\mathrm{Cd})$ mixture was +0.92 , indicating more-thanadditive interaction (Table 1 ). In the $(\mathrm{Cd}+\mathrm{Hg}$ ) combination, concentrations ranged from 0.4 to $1.2 \mathrm{ppm}$ of $\mathrm{Cd}$ along with $0.12 \mathrm{ppm}$ of $\mathrm{Hg}$. $\mathrm{LC}_{50}$ values (in toxic units) were $48 \mathrm{~h}, 1.0 ; 60 \mathrm{~h}, 0.81 ; 72 \mathrm{~h}, 0.76 ; 96 \mathrm{~h}, 0.66$. The additive index was +0.52 for $96 \mathrm{~h} \mathrm{LC}_{50}$ indicating a more-than-additive interaction (Table 1).

There was a decrease in the number of byssus threads produced with increasing concentration of $\mathrm{Hg}$, $\mathrm{Cd},(\mathrm{Hg}+\mathrm{Cd})$ and $(\mathrm{Cd}+\mathrm{Hg})$ (Fig. $1 \mathrm{a}$ to d). $\mathrm{Hg}$ concentrations of $0.038 \mathrm{ppm}$ and $0.029 \mathrm{ppm}$ caused a $50 \%$ reduction in the number of byssus threads produced during the dark and light phases of the experiments, respectively, whereas for $\mathrm{Cd}$ it was 0.73 and $0.87 \mathrm{ppm}$. In the $(\mathrm{Hg}+\mathrm{Cd})$ mixture, the effective concentrations to cause $50 \%$ reduction $\left(\mathrm{EC}_{50}\right.$ values) were $0.04 \mathrm{ppm}+0.3 \mathrm{ppm}$ (dark) and $0.008 \mathrm{ppm}+0.3$ ppm (light). In the $(\mathrm{Cd}+\mathrm{Hg})$ combination a concentration of $0.569 \mathrm{ppm}+0.03 \mathrm{ppm}$ and $0.97 \mathrm{ppm}+0.03$
Fig. 1. Perna viridis. Mean number of byssus threads secreted under sublethal concentrations of (a) $\mathrm{Hg}$, (b) $\mathrm{Cd}$, (c) $(\mathrm{Hg}+\mathrm{Cd})$, and (d) $(\mathrm{Cd}+\mathrm{Hg})$ during dark (D) and light (L) regimes ( $48 \mathrm{~h}$ each). Vertical bars: standard deviation

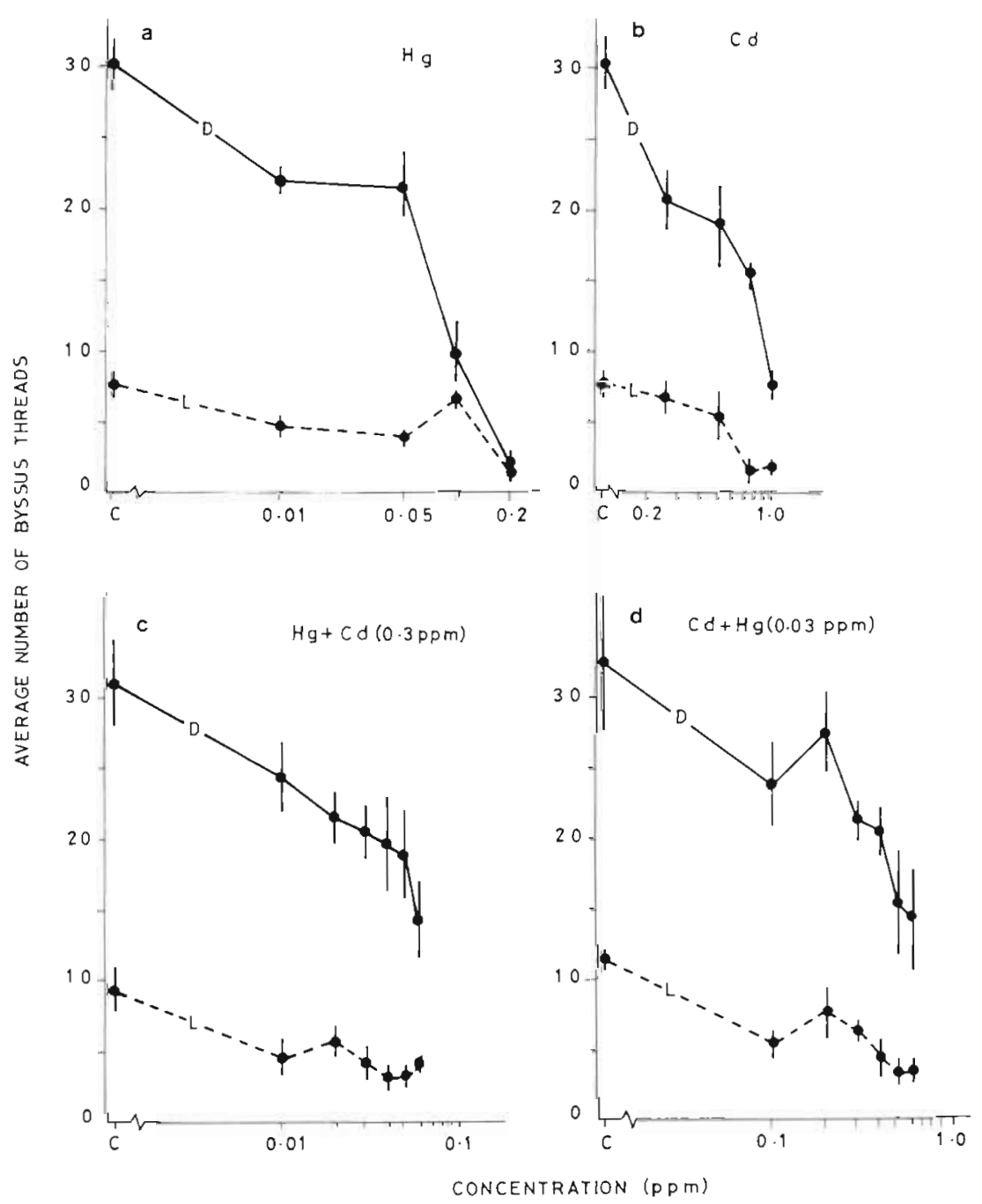


Table 3. Perna viridis. Effective concentrations $\left(\mathrm{EC}_{50} \mathrm{ppm}\right)$ which caused a $50 \%$ reduction in the number of byssus threads produced, filtration rate, and oxygen consumption. (Values based on regression analyses)

\begin{tabular}{cllll|}
\hline Metal & \multicolumn{2}{c}{ Byssogenesis } & Filtration rate & Oxygen consumption \\
& Dark phase & Light phase & \\
\hline $\mathrm{Hg}$ & 0.038 & 0.029 & 0.02 & 0.059 \\
$\mathrm{Cd}$ & 0.73 & 0.87 & 0.82 & 0.76 \\
$\mathrm{Hg}+\mathrm{Cd}$ & $0.04+0.3$ & $0.008+0.3$ & $0.014+0.35$ & Data insufficient \\
$\mathrm{Cd}+\mathrm{Hg}$ & $0.569+0.03$ & $0.97+0.03$ & $0.36+0.016$ & Data insufficient \\
\hline
\end{tabular}

ppm produced $50 \%$ reduction in the dark and light phases respectively (Table 3$)$. In both $(\mathrm{Hg}+\mathrm{Cd})$ and $(\mathrm{Cd}+\mathrm{Hg})$ combinations the metals produced either a less-than-additive or a more-than-addituve response in the rate of byssogenesis.

Fig. 2a to d gives the mean oxygen consumption rate of Perna viridis exposed to different concentrations of $\mathrm{Hg}, \mathrm{Cd},(\mathrm{Hg}+\mathrm{Cd})$ and $(\mathrm{Cd}+\mathrm{Hg}) . \mathrm{Hg}$ at $0.059 \mathrm{ppm}$ caused $50 \%$ reduction in oxygen uptake. Cd also individually depressed oxygen consumption; uptake was reduced by $50 \%$ at $0.76 \mathrm{ppm}$. $P$. viridis exhibited the following pattern of oxygen uptake when exposed to a combination of $(\mathrm{Hg}+\mathrm{Cd})$ : immediate reduction at lower concentrations, temporary elevation at medium concentrations and a subsequent decline reaching very low levels in the highest concentration. A combined concentration of $0.02 \mathrm{ppm} \mathrm{Hg}$ with $0.55 \mathrm{ppm} \mathrm{Cd}$ resulted in more than $50 \%$ reduction in oxygen consumption. In all the combined concentrations employed, the rate of consumption was less than that recorded in controls. In both combinations metals in mixtures reduced oxygen consumption to a greater extent than either of the metals did singly at lower individual concentrations. However, this trend was not maintained in higher concentrations, at least in the case of $(\mathrm{Cd}+\mathrm{Hg})$ mixture (Fig. 2c, d).

Mean filtration rates of Perna viridis exposed to different concentrations of $\mathrm{Hg}, \mathrm{Cd},(\mathrm{Hg}+\mathrm{Cd})$ and $(\mathrm{Cd}$ $+\mathrm{Hg})$ are presented in Fig. $3 \mathrm{a}$ to $\mathrm{d}$. $\mathrm{Hg}$ at a level of $0.02 \mathrm{ppm}$ resulted in $50 \%$ reduction in the quantity of water filtered, and a concentration of $0.2 \mathrm{ppm}$ caused $91 \%$ reduction in filtration rate. At $0.82 \mathrm{ppm} \mathrm{Cd}$ caused $50 \%$ reduction in filtration rate. Combinations of the 2 metals in $(\mathrm{Cd}+\mathrm{Hg})$ reduced filtration rates to

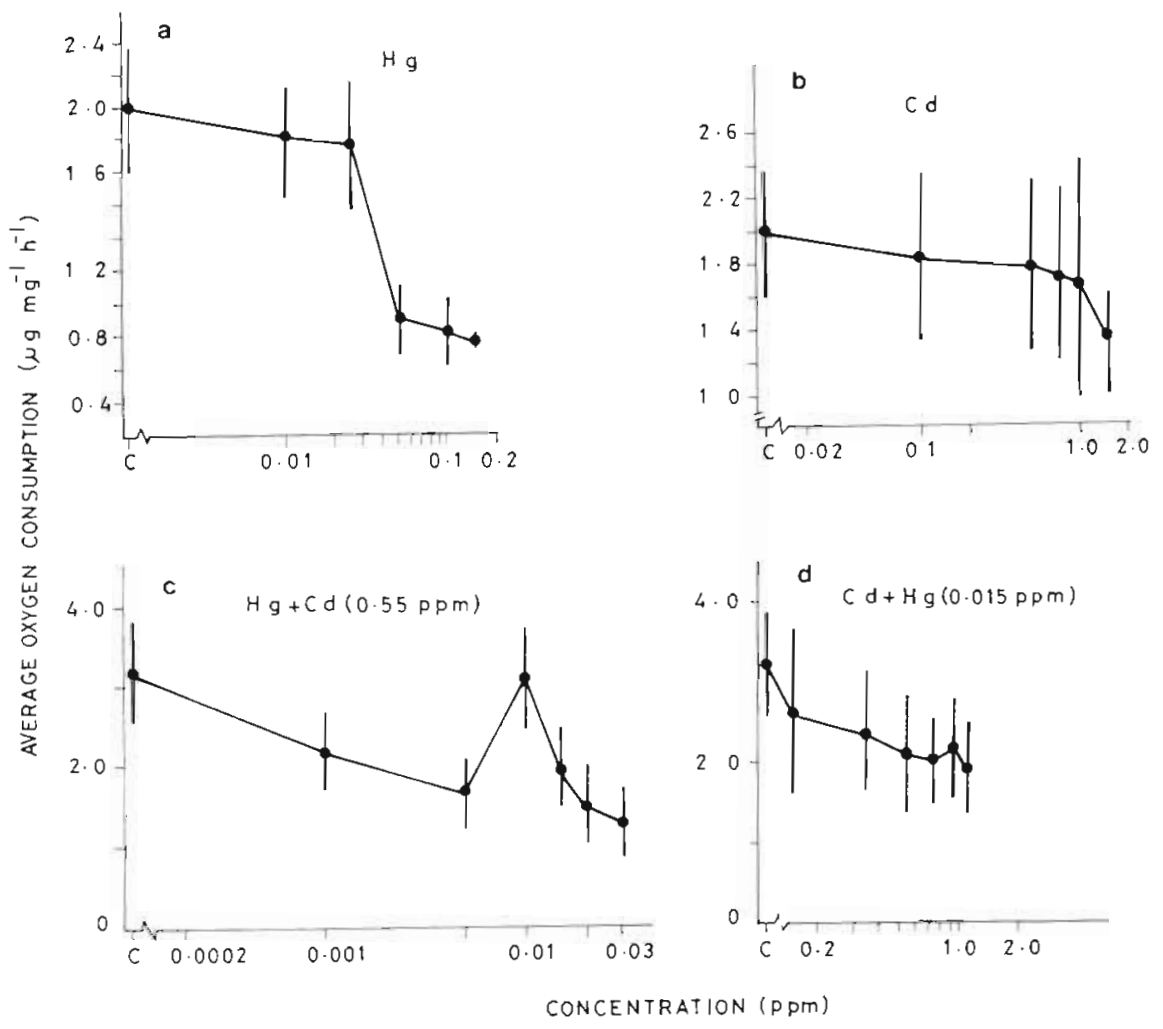

Fig. 2. Perna viridis. Average oxygen consumption (light) $\left(\mu \mathrm{O}_{2} \mathrm{mg}^{-1} \mathrm{~h}^{-1}\right)$ under sublethal concentrations of (a) $\mathrm{Hg}$, (b) $\mathrm{Cd}$, (c) $(\mathrm{Hg}+\mathrm{Cd})$ and (d) $(\mathrm{Cd}+\mathrm{Hg})$. Vertical bars: standard deviation 
Fig. 3. Perna vindis. Average rate of filtration (light) ( $\mathrm{ml}$ ind $\mathrm{in}^{-1} \mathrm{~h}^{-1}$ ) under sublethal concentrations of (a) $\mathrm{Hg}$, (b) (Cd), (c) $(\mathrm{Hg}+\mathrm{Cd})$, and (d) $(\mathrm{Cd}+\mathrm{Hg})$. Vertical bars: standard deviation

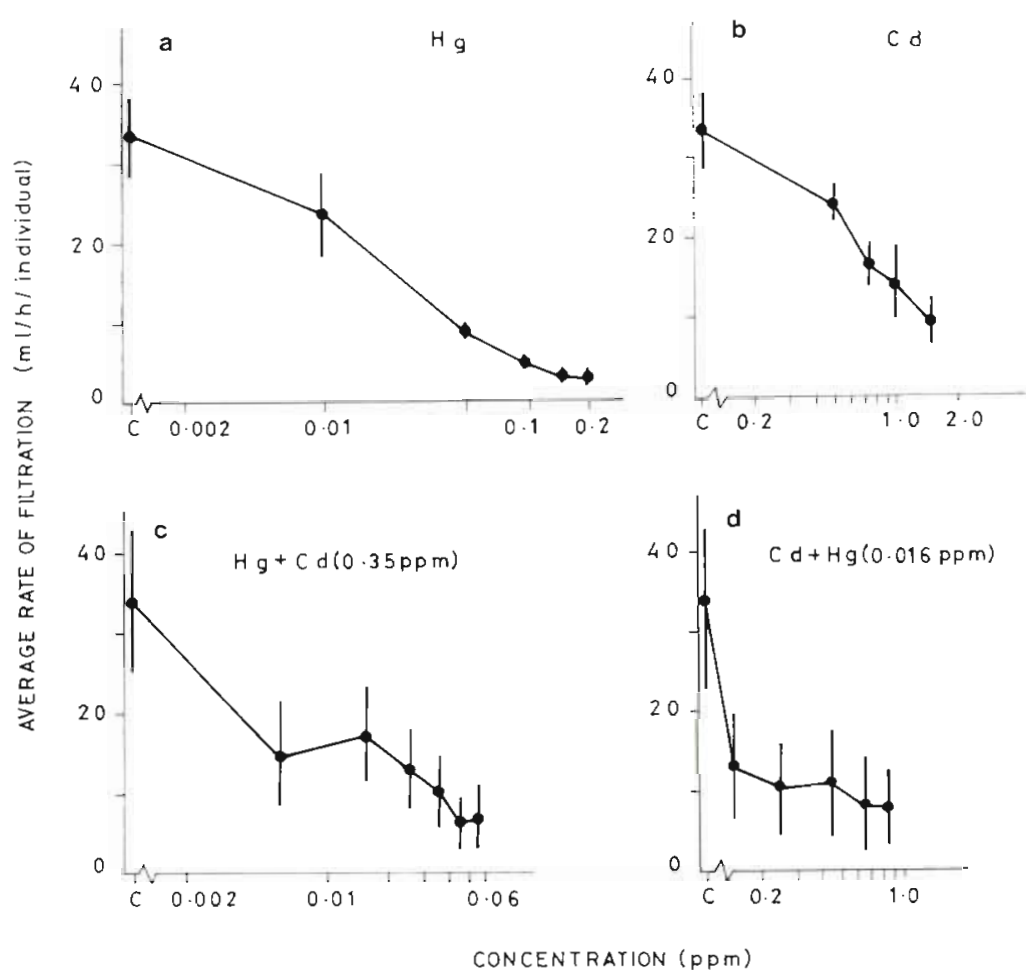

a greater extent than either of the metals individually, indicating more-than-additive interaction as observed with lethal toxicity (Table 1).

The results presented in Table 3 allow the following generalisations. Metals in combination can bring about more-than-additive or less-than-additive reactions of byssogenesis and filtration. The results obtained for byssogenesis indicate that metal concentrations which produced $50 \%$ reduction in performance can vary drastically depending on time of day (light/dark). Especially in the combination $(\mathrm{Hg}+\mathrm{Cd})$, $\mathrm{Hg}$ can exert little change in toxicity during the dark phase, while during the light phase, conspicuously low concentrations of $\mathrm{Hg}$ created deleterious effects.

\section{DISCUSSION}

The recent trend in heavy-metal studies is to analyse and predict lethal and sublethal toxicity levels of metal mixtures. Several studies (Sprague 1970, Spehar et al. 1978, Wong et al. 1978, Christensen et al. 1979, Eisler 1979) have stressed the importance of mixed toxicities in determining water-quality criteria. Interactions between metals may increase or decrease the degree of toxicity, depending upon the nature of individual pollutants. Since metals usually occur as mixtures in the marine environment, rather than alone, information on their interactions provides a more realistic assessment of their toxicity to marine organisms than observations with individual metals.

In the present study, the concentrations of $\mathrm{Hg}$ and $\mathrm{Cd}$ employed were considerably higher than the average mercury concentrations in seawater encountered in the northern hemisphere. According to Florence \& Batley (1980), this is $0.03 \mathrm{ppb}$. Mytilus edulis is reported to survive and grow at reduced pace in $0.3 \mathrm{ppb}$ (Strömgren 1982). The high concentrations used in the present study were a compromise for the time factor, as the experimental duration was short. Further, laboratory studies showed that Perna viridis remained active for more than $1 \mathrm{wk}$ at concentrations as high as $0.1 \mathrm{ppm}$ $\mathrm{Hg}$ and $0.8 \mathrm{ppm} \mathrm{Cd}$ (own unpubl. data). The Marking \& Dawson (1975) additive indices of +0.92 and +0.52 , respectively, for $(\mathrm{Hg}+\mathrm{Cd})$ and $(\mathrm{Cd}+\mathrm{Hg})$ combinations, reveal joint interaction, i.e. more than additive in bringing about mortality of test specimens. Even though both combinations produced a more-than-additive effect, the additive index was higher in the $\mathrm{Hg}+$ Cd) combination. This suggests that varying concentrations of $\mathrm{Hg}$ with a constant concentration of $\mathrm{Cd}$ in the test medium were relatively more lethal to $P$. viridis. The higher additive index reflects 2 things: firstly, the involvement of a more-than-additive (synergistic) interaction; secondly, low levels of 2 metals causing a fixed response. It is evident that the concentrations of metals in mixtures also affect the degree to which component interactions are additive or synergistic. A 
comparable result was obtained when $P$. viridis was subjected to combinations of zinc and copper (Prabhudeva \& Menon 1986).

Literature on the combined toxicities of $\mathrm{Hg}$ and $\mathrm{Cd}$ to bivalves is limited. The reasons for the increased toxicities of mixtures are still not clearly understood. These may include increase in the rate of uptake, formation of toxic metabolites, reduction in excretion, alteration of distribution, and inhibition of detoxification (Moulder 1980). This could account at least partially for the results obtained in the present study. The presence of 2 metal ions in the test medium may accentuate toxic effects at comparatively low concentrations. Perhaps, depurative processes of the mussel are affected deleteriously when forced to ward off 2 metal ions.

Several workers have studied the toxicity of metal mixtures, and a few have considered possible reasons for increased or decreased toxicities of metal mixtures. Barnes \& Stanbury (1948) found that mixtures of cupric sulphate and mercuric chloride were far more toxic to the copepod Nitocra spinipes than either of the salts alone. Comer \& Sparrow (1956) reported that $50 \mathrm{ppm}$ of mercury (as $\mathrm{HgCl}_{2}$ ), in $23 \mathrm{~h}$, or $1000 \mathrm{ppm}$ of copper (as copper sodium citrate) caused $50 \%$ mortality of Artemia salina, whereas $25 \mathrm{ppm}$ of $\mathrm{Hg}$ and $500 \mathrm{ppm}$ of $\mathrm{Cu}$ killed $50 \% \mathrm{~A}$. salina in $23 \mathrm{~h}$ indicating a clear-cut additive reaction. Additive effects of $\mathrm{Hg}$ and $\mathrm{Cu}$ have been documented in developing sea urchin eggs (Marakkami et al. 1976). MacInnes \& Calabrese (1977) reported the interaction of metals to be temperature dependent. Antagonism and less-than-additive interactions have also been documented for $\mathrm{Hg}$ and $\mathrm{Cu}$ mixtures. Moulder (1980) observed the protective action of $\mathrm{Cu}$ against the toxic action of $\mathrm{Hg}$ in the euryhaline amphipod Gammarus duebeni. Her reasons for the resulting less-than-additive interaction were: (1) the possibility of $\mathrm{Cu}-\mathrm{Hg}$ complex formation, thereby reducing $\mathrm{Hg}$ availability; (2) $\mathrm{Cu}$ occupying binding sites on the surface of the gammarid that would be otherwise occupied by $\mathrm{Hg}$; (3) $\mathrm{Cu}$ detoxifying $\mathrm{Hg}$ within the tissue.

Byssogenesis has been employed as a useful tool to assess sublethal pollutant effects in Mytilus edulis (Roberts 1975) and Perna viridis (Eknath \& Menon 1979, Reddy \& Menon 1979, Mathew \& Menon 1983). Byssus-thread production could be affected by reduced pedal activity, differences in shell closure ability, or direct interference in the synthesis of byssal threads. In the present study $\mathrm{Hg}$ concentrations of 0.029 to 0.038 ppm reduced byssal-thread production by $50 \%$ during light and dark phases respectively. This observation is in general accordance with that reported by Martin et al. (1975). Byssal-thread production was inhibited at Cd levels of 0.25 ppm and above; thread production was reduced by $50 \%$ at $\mathrm{Cd}$ levels of 0.73 or $0.87 \mathrm{ppm}$ depending on the time of observation. By comparison, Briggs (1979) observed inhibition of byssal-thread production in $M$. edulis at concentrations between 1.0 and $5.0 \mathrm{ppm} \mathrm{Cd}$. Comparison of the results with $\mathrm{EC}_{50}$ values of individual metals reveals the possibility of the 2 metals acting less than additively in decreasing byssogenesis. The combination $\mathrm{EC}_{50}$ values were well below the $96 \mathrm{~h} \mathrm{LC}_{50}$ values (Table 3).

Changes in oxygen consumption are valuable indicators of sublethal stress and are frequently used to evaluate changes in metabolism due to environmental alteration (Hawkins et al. 1986). Oxygen uptake in Perna vinidis decreased with increasing $\mathrm{Hg}$ levels; Concentrations between 0.04 and 0.05 ppm reduced uptake by 50 to $60 \%$, about $1 / 5$ of the $96 \mathrm{~h} \mathrm{LC}_{50}$ value (Fig. 2a to d). A similar observation was recorded for Cd. In $P$. viridis exposed to $\mathrm{Hg}+\mathrm{Cd}$ combined, oxygen uptake showed a general decreasing trend with increasing concentrations. The combination of $\mathrm{Cd}+\mathrm{Hg}$ also depressed oxygen uptake in $P$. viridis. Bivalve molluscs can turn to anaerobiosis under unfavourable conditions. Salanki $(1965,1968)$ observed that bivalves close their valves tightly and stop filtering under unfavourable conditions resulting in decreased oxygen uptake. Since complete valve closure in $P$. viridis is not possible due to interference by the byssal mass, some water may enter. Rhythmic shell movements in bivalves are closely related to respiration and filtration rate (Morton 1970, Reddy \& Menon 1979, Mathew \& Menon 1983). Oxygen consumption in bivalves represents the product of 2 factors: ventilation volume and efficiency of gas exchange. Hence fluctuations in respiratory levels may be due to variation in the water volume moved through the gills and to interruptions.

Variations in filtration rate are valuable indicators of sublethal stress. The filtration-rate test is based on an organismic response of ecological significance, since bivalves depend on the water they filter for both food and oxygen.

Perna viridis filters considerably less water under Hg stress. According to Epifanio \& Srna (1975) filtration rate in bivalves is reduced under pollutional stress. Filtration rate can be affected by at least 3 important factors: frequency of valve closure, rate of ciliary acitivity, and changes in the level of gill irrigation (Reddy \& Menon 1979). Under Cd stress, P. viridis temporarily elevates filtration rates at lower concentrations; at higher concentrations there is a clear-cut reduction. $(\mathrm{Hg}+\mathrm{Cd})$ combinations cause considerable reduction in filtration rate; this indicates that the metals in combination are more harmful than either of them alone.

A conspicuous feature of this study is that lethal and sublethal effects did not reflect the same trend in metal 
additive reactions. While concentrations of heavy metal salts employed in combination may produce more-than-additive lethality, such reactions need not be reflected at sublethal levels. The reason may be that the concentrations selected for the sublethal toxicity tests were well above thresholds and hence, individual-metal-induced reactions in the mixture could not be delineated. It is possible that concentrations at ppb levels, if employed, would have given sublethal results comparable to those of lethal effects, as found in the case of Perna indica (Menon \& Baby unpubl. data).

\section{LITERATURE CITED}

Barnes, H., Stanbury, F. A. (1948). The toxic action of copper and mercury salts both separately and when mixed on the herpacticoid copepod Nitocra spinipes (Boeck). J. exp. Biol. 25: 270-275

Briggs, L. B. R. (1979). Effects of cadmium on the intracellular pool of free amino acids in Mytilus edulis. Bull. environ. Contam. Toxicol. 22: 834-845

Bryan, G. W. (1984). Pollution due to heavy metals and their compounds. In: Kinne, O. (ed.) Marine ecology, Vol. V. Ocean management, Chap. 3. Wiley, Chichester, p. $1289-1431$

Calabrese, A., Nelson, D. A. (1974). Inhibition of embryonic development of the hard clam Mercenaria mercenaria by heavy metals. Bull. environ. Contam. Toxicol. 11: 92-97

Christensen, E. R., Scherfig, J., Dixon, P. S. (1979). Effects of manganese, copper and lead on Selenastrum capicarnutum and Chlorella stigmatiphora. Wat. Res. 13: 79-92

Corner, E. D. S., Sparrow, B. M. W. (1956). The modes of action of toxic agents I. Observations on the poisoning of certain Crustacea by copper and mercury. J. mar. biol. Ass. U.K. 35: $531-548$

Davies, A. G. (1978). Pollution studies with marine plankton. Part II. Heavy metals. Adv. mar. Biol. 15: 381-508

Eisler, R. (1971). Cadmium poisoning in Fundulus heteroclitus and other marine organisms. J. Fish. Res. Bd Can. 28: $1225-1234$

Eisler, R. (1979). Toxic actions and marine biota: analysis of research effort during the three-year period 1974-1976. In: Vernberg, W. B., Thurberg, F. P., Calabrese, A., Vernberg, F. J. (ed.) Marine pollution: functional responses. Academic Press, New York, p. 111-149

Eknath, A. E., Menon, N. R. (1979). Effect of organo-chlorines on the life and activity of non-target marine animals. In: Edwards, C. A., Veeresh, G. K., Krueger, H. R. (ed.) Symposium on pesticide residues in the environment in India, Allied Publisher, Bangalore, p. 513-519

Epifanio, C. E., Srna, R. F. (1975). Toxicity of ammonia, nitrite ion, nitrate ion and orthophosphate to Mercenaria mercenaria and Crassostrea virginica. Mar. Biol. 33: 241-246

Florence, T. M., Batley, G. E. (1980). Chemical speciation in natural waters. Crit. Rev. analyt. Chem. 9 (1): 219-296

George, S. G. (1983). Heavy metal detoxication in Mytilus kidney - An in vitro study of $\mathrm{Cd}$ and $\mathrm{Zn}$-binding to isolated tertiary lysosomes. Comp. Biochem. Physiol. 76C: $59-65$

George, S. G., Frazier, J. M. (1982). Some aspects of the relationship between tolerance to heavy metal pollution and metabolism of $\mathrm{Cd}, \mathrm{Cu}$ and $\mathrm{Zn}$ in oysters. Thalassia jugosl. 18: 203-219

Goldberg, E. D., Bowen, V. T., Farrington, J. W., Harvey, G.,
Martin, J. H., Parker, P. L., Risebrough, R. W., Robertson, W., Schneider, E., Gamble, E. (1978). The mussel watch. Environ. Conserv. 5: 101-125

Hawkins, A. J. S. (1985). Relationships between the synthesis and breakdown of protein, dietary absorption and turnovers of nitrogen and carbon in the blue mussel, Mytilus edulis L. Oecologia (Berl.) 66: 42-49

Hawkins, A. J. S., Bayne, B. L. (1985). Seasonal variation in the relative utilization of carbon and nitrogen by the mussel Mytilus edulis: budgets, conversion efficiencies and maintenance requirements. Mar. Ecol. Prog. Ser. 25: $181-188$

Hawkins, A. J. S., Bayne, B. L., Menon, N. R., Damodaran, R. (1986). The mussels Perna viridis and $P$. indica as transplantable indicators of pollution: comparison of their metabolic response to reductions of both oxygen tension and salinity. In: Menon, N. R. (ed.) Proceedings National Seminar on Mussel Watch, Vol. 1. Cochin University Publ., Cochin, p. 51-65

Johnston, R. (1976). Mechanisms in marine pollution. In: Johnston, R. (ed.) Marine pollution. Academic Press, London, New York, p. 3-161

MacInnes, J. R., Calabrese, A. (1977). Responses of the embryos of the American oyster Crassostrea virginica to heavy metals at different temperatures. In: Mclusky, D. J., Berry, A. J. (ed.) Physiology and behaviour of marine organism. Pergamon Press, New York, p. 195-202

Marking, L. L., Dawson, V. K. (1975). Method for assessment of toxicity or efficacy of mixtures of chemicals. In: Investigations in fish control, No. 67, U.S. Department of the Interior Fish and Wildlife Service, p. 1-7

Martin, J. M., Piltz, F. M., Reish, D. J. (1975). Studies on the Mythilus edulis community in Alamiter Bay, California. V. The effects of heavy metals on byssal thread production. Veliger 18: 183-188

Mathew, R., Menon, N. R. (1983). Oxygen consumption in tropical bivalves Perna viridis (Linn.) and Meretrix casta (Chem.) exposed to heavy metals. Indian J. mar. Sci. 12: $57-59$

Mohan, C. V., Menon, N. R., Gupta, T. R. C. (1984). Toxicity of cadmium to six intertidal invertebrates. Fish. Tech. 21: $1-5$

Morton, B. (1970). The tidal rhythm and rhythm of feeding and digestion in Cardium edule. J. mar. biol. Ass. U.K. 50: $499-512$

Moulder, S. M. (1980). Combined effect of the chlorides of mercury and copper in sea water on the euryhaline amphipod Gammarus duebeni. Mar. Biol. 59: 193-200

Murakkami, T. H., Fujii, T., Hara, T., Kishida, A. (1976). The effects of heavy metals on developing sea urchin eggs. J. Okayama Med. Soc. 88: 39-50

Nelson, D. A., Calabrese, A., Nelson, B. A., Macinnes, J. R., Wenzloff, D. R. (1976). Biological effects of heavy metals on juvenile bay scallops Argopecten irradians in short term exposures. Bull. environ. Contam. Toxicol. 16: 275-282

Nelson, D. A., Calabrese, A., MacInnes, J. R. (1977). Mercury stress on juvenile bay scallops, Argopecten irradians, under various salinity-temperature regimes. Mar. Biol. 43: 293-297

PIabhudeva, K. N., Menon, N. R. (1986). Toxicity of metal mixtures on Perna viridis (L.) (Mollusca; Pelecypoda). Presented in the First Asian Fisheries Forum 25-31 May, Manila, Philippines. Asian Fisheries Society, Manila, p. 216 (Abstract)

Qayle, D. B. (1948). Biology of Venurupis pullastra (Montague). Dissertation, Univ. of Glasgow (mimeo) 
Reddy, N. A., Menon, N. R. (1979). Effects of ammonia and ammonium on tolerance and byssogenesis in Perna viridis. Mar. Ecol. Prog. Ser. 1: 315-321

Reish, D. J., Carr, R. S. (1978). The effects of heavy metals on the survival, reproduction, development and life cycles for two species of polychaetous annelids. Mas. Pollut. Bull. 9: 24-26

Roberts, P. (1975). The effect of pesticides on byssus formation in the common mussel, Mytilus edulis. Environ. Pollut. 8 : 241-254

Salanki, J. (1965). Oxygen level as a specific regulator of the rhythmic activity of freshwater mussel Anodonta cygenea. Acta. biol. Acad. Sci. Hung. 15: 299-310

Salanki, J. (1968). Role of cerebral ganglia in the regulation of activity in freshwater mussel Anodonta cygnea. In: Salanki, J. (ed.) Neurobiology of invertebrates. Akade 'miai Kiado', Budapest, p. 493-501

Spehar, R. L., Leonard, E. N., Defoe, D. L. (1978). Chronic toxicity of cadmium and zinc mixtures on flagfish Jordanella floridae. Trans. Am. Fish. Soc. 107: 354-360
Sprague, J. B. (1970). Measurement of pollutant toxicity to fish. II. Utilising and applying bioassay results. Wat. Res. 4: $3-32$

Strömgren, T. (1982). Effect of heavy metals ( $\mathrm{Zn}, \mathrm{Hg}, \mathrm{Cu}, \mathrm{Cd}$, $\mathrm{Pb}, \mathrm{Ni}$ ) on the length growth of Mytilus edulis. Mar. Biol. 72: $69-72$

Waldichuk, M. (1974). Some biological concerns in heavy metal pollution. In: Vermberg, F. J., Vernberg, W. B. (ed.) Pollution and physiology of marine organism. Academic Press, New York, p. 1-57

Weis, J. S. (1978). Interactions of methylmercury, cadmium, and salinity on regeneration in the fiddler crabs, Uca pugilator, U. pugnaz and U. minax. Mas. Biol. 49: 119-124

Weis, P., Weis, J. S. (1978). Methylmercury inhibition of fin regeneration in fishes and its interaction with salinity and cadmium. Estuar. coast. mar. Sci. 6: 327-334

Wong, P. T. S., Chan, Y. K., Luzon, P. L. (1978). Toxicity of a mixture of metals on freshwater algae. J. Fish Res Bd Can. 35: $479-481$ 